\title{
DISCOURSE AND SILENCE IN MARTIANUS CAPELLA'S DE NUPTIIS PHILOLOGIAE ET MERCURII ${ }^{1}$
}

\author{
By Julieta Cardigni
}

\begin{abstract}
Summary: The present paper analyzes Martianus Capella's De nuptiis Philologiae et Mercurii from a generic point of view, departing from Systemic Functional Linguistics, in order to establish parody as its main feature, in consistence with its generic adscription to Menippean Satire. As a result, we expect to prove that Martianus is attacking discourse and discursive knowledge, and proposing silence as an alternative category for the characterization of transcendence and truth. This perspective intends to show De nuptiis as a Menippean Satire which subverts all values exposed along the work, turning thus into an anti-didactic text.
\end{abstract}

\section{PROBLEMS WITH AND PERSPECTIVES ON MARTIANUS' RECEPTION: A SHORT REVIEW}

As modern readers, it may be difficult for us to approach Martianus Capella's De nuptiis Philologiae et Mercurii without ascribing a didactic purpose to it. Given the fact that a large part of the work (seven of its nine constituent books) consists of an exposition of the seven Liberal Arts, it

1 I would like to express my sincere gratitude to Prof. Robert Kaster, who was my advisor during my research stay at Princeton as a Fulbright Visiting Scholar. His suggestions and comments were an invaluable guide to shape the ideas that are now part of the present article. I am also very grateful to Professor Joel Relihan for his inspiring opinions and remarks on the subject.

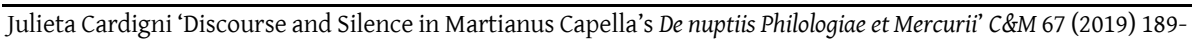
218. 
seems plausible to assume that its main goal is to instruct in the disciplines displayed there. Medieval readers saw it precisely this way: they found in Martianus' work a cumulative and thematically organized (though somewhat incomplete and micro-structurally incoherent) corpus of ancient knowledge. To this corpus, the author attaches a seemingly allegorical fable that seems to act as an amusing introduction and frames the exposition of the Liberal Arts.

However, to assume from this that Martianus wrote a didactical work would be a mistake, and this is the main point that I will attempt to elucidate here. This generic formal label of "encyclopedia," forced upon the work over centuries of reception, doesn't provide much help in understanding it; it is an inadequate designation that fails to explain many of the work's aspects. ${ }^{2}$ When considered according to this label, De nuptiis comes off as an encyclopedia that is bizarre and incomprehensible, and in addition to the problems that this causes, resistance to reevaluating its generic discursive pertinence is very strong. An overall result of this has been the prevailing idea that Martianus' work is a product that lies outside of time and space, one that is strange even for its own Baroque period, isolated from the literary universe, a kind of freak that lurks alone in the history of literature. Despite this use that posterity has made of De nuptiis ("use" rather than "reading" because medieval scholars seemed to be sharply aware of its many ambiguities), ${ }^{3}$ I am convinced that true understanding of the work requires a new approach that will

2 Among these, as we will see, are the mixture of tones and registers found throughout the work, the Menippean mold that Martianus obviously applies, the alternating presence of seriousness and comedy, the strange presentation of the Liberal Arts (incomplete and sometimes incoherent), and the figure of the narrator: incompetent and ridiculous at any level of reading.

3 The Carolingian scholar John Scotus Eriugena certainly is, when he states about Martianus that: (...) ita fuisse finxerit philosophus esse, veluti quidam histrio nominatus est, falsa quippe poetico usu veris philosophiae rationibus intermiscuit. "Thus, he pretended to be a philosopher, as if he has taken the name from some actor, and for that reason he mixed false things, according to the poetic use, with the reasons of true Philosophy." (The Latin text is from Ramelli's edition 2006, and the translation is mine.) Eriugena understands Martianus' parodic game as well as his literary persona but, as a schoolmaster, he decides to read the text with a didactic purpose and in a fragmentary way, focusing on the treatises containing the Liberal Arts. 
allow us to view it in its full scope. This approach must be literary and discursive, even though the content of the so-called treatises may be considered disciplinary. In fact, when we ask ourselves if that disciplinary exposition may itself be a literary resource, a different approach opens up, one that is more promising than simply pigeonholing the work either as a failed encyclopedia or a wearisome catalogue of silly puns or the didactical monster that results from the wedding of the two. The internal logic of De nuptiis only appears in its full light when we consider it as a literary device belonging to a particular cultural context, generic universe and literary tradition with which it entertains a dialogue.

As I have suggested, the knot of conflict with regards to the reading of De nuptiis can be glimpsed if we observe the history of its reception. To begin with, we have no reference as to how Martianus' contemporaries might have read or made use of De nuptiis. His posterity, on the other hand, began immediately to read, reproduce and use it ostensibly, as can be seen from the number of manuscripts made of it during the $9^{\text {th }}$ and $10^{\text {th }}$ centuries, and especially from the profusion of didactic commentaries and annotations made on it from this same period onward. ${ }^{4}$ By medieval times, scholars already lacked the numerous sources that Martianus had used to compose his work, and so it seems logical that they should seize upon the knowledge condensed in De nuptiis. ${ }^{5}$ The problem lies in that these readings - legitimate and in their own way worthwhile - established a line of interpretation of the work that is didactic and of which, to the present day, it is difficult to let go, a didactic line of interpretation that places the text in an uncomfortable container, making deep understanding of it difficult.

Within this interpretive tradition, the approaches to Martianus' work, none of which has yet reached the status of communis opinion, ${ }^{6}$ may be organized into these three broad classes:

4 On manuscripts of De nuptiis and their trajectories, cf. Leonardi 1955.

5 For a clear look at the reception of De nuptiis, cf. LeMoine 1972.

6 Regarding the communis opinio on Martianus' work, many other aspects are unclear, the date of composition of De nuptiis being one of them. For a status quaestionis, see Cameron 1986; Shanzer 1986; Relihan 1987. In agreement with these two latter scholars, we will place the composition of De nuptiis in the latter part of the fifth century. 
a) The perspective in which the genre of De nuptiis is not a matter of discussion, since interest focuses instead on its philosophical content. ${ }^{7}$ In some cases De nuptiis is categorized as a Menippean satire as a whole, but this label plays no real role in the general consideration of the work. ${ }^{8}$

b) The perspective that considers De nuptiis a didactical work in which the literary generic model of Menippean satire (if treated), the use of parody and the use of fictionalization all serve the purpose of encyclopedic instruction. This perspective implies a sort of division of the work into two discernible and isolated components: the introductory allegorical fable of Books 1-2 followed by seven "serious" Books in which each of the Liberal Arts is explained. ${ }^{9}$

c) The approach of Relihan 1987 and $1993^{10}$ which shows more interest in the analysis of the discursive genre and its consequences for the reading of the work. Relihan goes as far as to propose that De nuptiis is a Menippean satire in which parody is a central issue, and encyclopedic knowledge is mocked. According to Relihan, who does not completely relinquish the notion of an ultimately pedagogical goal, this failed encyclopedia would seek to provide us with a lesson on confidence in bookish knowledge that takes for granted its own omniscient familiarity with the secret order of the world. In this direction we can also find the very recent (and far-reaching) approach of Cullhed 2015, which considers De nuptiis to be a critique of the mediation of fictional discourse, without which knowledge would be intransmissible. From Cullhed's perspective, more in accordance with Relihan's and ours, De

7 This is the case of Lenaz 1975 and Turcan 1954.

8 Shanzer 1986 accepts the Menippean label, but she does not deal with the ultimate implications of it since, as she advises the readers, she will focus on aspects of the work that are more related to its philosophical content.

9 Authors who approach the work from this perspective include Petrovicova 2010; Westra 1981; 1988. Bakhouche 2011 and 2015 observes the self-directed irony of the narrator, but limits this consideration to isolated episodes and does not project it out to the work as a whole.

10 Relihan 1993 not only proposes reading De nuptiis as a Menippean satire, but also gives us a history of the genre in Antiquity. This provides a cultural and traditional context within which the work can be read and enables it to enter into dialogue with its literary precedents and successors. 
nuptiis is a parody of itself, constantly mocking and destabilizing the literary genres present in it. ${ }^{11}$

Most of these approaches don't offer a systematic and thorough study of the discursive genre, and therefore they are not able to assess the aims of the work properly. More than being a mere formal tag, the concept of Genre should be considered functional and intimately related to the nature and purpose of the text (any text). De nuptiis is an example of this: if we are to consider that the work is a vehicle for friendly didacticism, it is necessary for modern criticism to postulate a mixture of Menippean satire and encyclopedia for which there are no known precedents in Ancient literature. Moreover, the expositions of the Arts are interrupted or, in some cases, left unfinished through the dismissal of an impatient host. Setting aside the practical use that readers of the Middle Ages might have made of the work, one can legitimately ask what the functional value of such an artifact could have been to Martianus' contemporaries. Although Relihan's approach goes far in stressing the importance of genre and its implications, I believe it is possible to go even further. In basic agreement with Cullhed's proposal, I will expand his view to include all forms of discourse, not only fictional discourse.

This exegetic movement that I propose is achieved by approaching the work from the standpoint of its literary genre, and its literary genre in turn from a functional perspective. Working in this way, at least three problems related to the interpretation of De nuptiis can be resolved:

- the supposed didacticism of the work, which functions as an a priori notion, into agreement with which reading of the work and its generic adscription have been forced;

11 In a more general way, Rollo 2011 also mentions the issue of language in Martianus, although he elaborates little on the subject. The very recent work of Hernández Lobato 2017 speaks of a "poetic" of Late Antiquity, taking discourse and silence into account as significative elements. Although this compilation includes no study of Martianus Capella's work, the perspective it offers has characteristics similar to mine. 
- the work's fragmentary nature, given that those who recognize the existence in it of parody, self-directed irony on the part of the narrator, and fictional elements, limit these to the first two books, placing the other seven in the separate category of "scientific knowledge"; - and finally, the resulting disconnection between the two parts of the work referred to just above.

Conceiving of De nuptiis as a Menippean satire implies the application of a prevailing critical agenda of parody, against which the didactic element can only be undermined, making the work a profoundly anti-didactic one. In addition, parody works as a unifier and connector of both sections. De nuptiis not only contains parody; it is a parody.

This being said, it must be recognized that, due to parody's ambiguous and elusive nature, any study of it requires the use of precise theoretical instruments. The phenomenon of parody is one that is easy to recognize if looked for, but apparently imperceptible if we refuse to recognize it although such refusal can lead to problems of reading that are difficult to resolve - and difficult to establish and analyze systematically, even when we are convinced of its presence. For this reason, I apply the theoretical framework of Systemic Functional Linguistics (SFL), taken by the Sydney School from the Bakhtinian perspective. This provides concrete elements of discursive analysis for the purpose of approaching the study of parody. ${ }^{12}$ According to this line of thinking, although the prosimetrum is traditionally the central feature from which Menippean satire is recognized, its formal nature makes it a necessary, but not a sufficient, condition. Many works alternate prose and verse, but not all of them are Menippean satires; it is necessary to perceive what function verse serves in order to activate one or another key of generic reading. Also, in SFL, the social purpose of a text is what determines its literary genre. For example, although we can find a certain systematization of knowledge in De nuptiis, it is not a didactic work if its social purpose is not that of instruction. If it is rather to unbalance or attack common cultural spaces by means of parody, then this feature - added, in context, to others that lead in the same direction - points to the destabilizing and critical genre

12 On SFL, see Eggins \& Martin 2003; Halliday \& Hasan 1976; Halliday 1989; Halliday \& Matthiessen 2004; Martin \& Rose 2007. 
of Menippean satire. In this case we can then, as medieval scholars did, read the work in order to know (perhaps) what the rhetoric was about, but doing so does not mean that the social purpose of the work is necessarily that of a manual on Rhetoric. This does not hold up when we study the work as a whole or when we consider didacticism as a discursive phenomenon textualized through specific strategies recognizable by author and reader.

Added to this, the SFL concept of contextual metaphor is very enlightening with regards to detecting the presence of parodic register, and it helps explain the phenomenon of generic displacement that often arises in interpretations of polyphonic and heterogeneous works like De nuptiis. According to this idea, a genre can activate certain features that set the stage attributable to a determined genre; yet at the same time it can reverse this impression and frustrate the reader's expectations by bringing out features that resignify the generic adscription and, consequentially, the interpretation of the work. In the case of Martianus, perception of the parodic register resignifies this set stage and, at the same time, the discursive genre of the work, which goes from being a didactic manual to a Menippean satire. This rapprochement not only allows for an important flexibility in the study of literary genre, but also explains the confusion and imprecision with regards to the generic adscription of the De nuptiis, since didactic elements are indeed present in the work, but only insofar as to function as objects of parody and subversion.

Let's accept, then, that De nuptiis is a parody. But a parody of what? As we know, there is no such thing as harmless parody; there is always in its scope a set of values intended to subvert. The narrative situation of the epithalamium is parodied, the knowledges and their function as guides for the spiritual ascent are parodied, the magister-discipulus relationship is parodied, as well as its projections and possibilities. But most especially - and in a mustering up of all of these things - discourse is parodied: its possibilities as a vehicle for the transmission of knowledge, its communicative possibilities, its capability for being a path to the truth, and finally, its function as a mediator between the human and the divine - in other words, all that is promised in the title through the image of nuptials, which end up never taking place. De nuptiis is, therefore, a liter- 
ary text of which parody is a constitutive feature rather than a mere resource. The use of parody here is not only to criticize bookishness and learned knowledge, but to question the universe of discourse - even that very part of it of which the work is an example. Therefore, what is at issue here is the non-transcendent nature of verbal communication, both among human beings and between human beings and the divine.

\section{PARODY, DISCOURSE, AND THE EMERGENCE OF SILENCE}

So the moment has arrived to show how, by means of discursive analysis, the deep meaning of the work is revealed. Of course, within the scope of this article only a few representative examples can be treated: one which places in evidence the self-directed irony of the narrator, another related to the parodic presentation of the Liberal Arts, and finally a passage in which we can observe the withdrawal of parody and the appearance of silence as a category in opposition to that of the besieged discourse. ${ }^{13}$

De nuptiis begins with a hymn dedicated to Hymen (symbol of the cosmic union of the elements), full of Platonic (Porphyrian) allusions and even a trace of Lucretius: ${ }^{14}$

Tu quem psallentem thalamis, quem matre Camena progenitum perhibent, copula sacra deum, semina qui arcanis stringens pugillantia ${ }^{15}$ vinclis complexuque sacro dissona nexa foves, namque elementa ligas vicibus mundumque maritas atque auram mentis corporibus socias,

13 For an exhaustive study of Martianus Capella from this same perspective, cf. Cardigni, De nuptiis Philologiae et Mercurii o la farsa del discurso. Una lectura literaria de Marciano Capela, Editorial de Publicaciones de la Facultad de Filosofía y Letras, Universidad de Buenos Aires, Buenos Aires (pending publication 2018).

14 On the philosophical content of this verse prologue, cf. Schievenin 2007-2008; LeMoine 1972; Ramelli 2001.

15 Dick's pugnantia instead of pugillantia results in no change of meaning in the translation. Neither do the subtle changes in punctuation observed in the two Latin texts. 


\section{foedere complacito sub quo natura iugatur, Sexus concilians et sub amore fidem; o Hymenaee decens, Cypridis quae maxima cura es (hinc tibi nam flagrans ore Cupido micat), seu tibi quod Bacchus pater est placuisse choreas, cantare ad thalamos seu genetricis habes, comere vernificis florentia limina sertis ceu consanguineo Gratia trina dedit: conubium divum componens Calliopea carminis auspicio te probat annuere. ${ }^{16}$}

Following this hymn, and in strong contrast to it, is a prose prologue (1.12):

Dum crebrius istos Hymenae versiculos nescioquid inopinum intactumque moliens cano, respersum capillis albicantibus verticem incrementisque lustralibus decuriatum nugulas ineptas aggarrire non perferens Martianus intervenit dicens 'quid istud, mi pater, quod nondum vulgata materia cantare deproperas et ritu nictantis

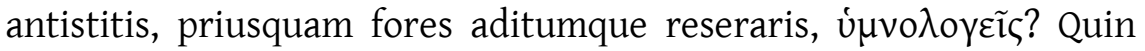

16 Since I wouldn't dare attempt a translation to English - a language not my own - I will use Stahl's translation for Martianus' text (1977). However, since Willis' edition (on which most modern editions and translations are based) had not been published yet, Stahl used Dick's edition (1925). I am following Willis' text, which has become canonical. Therefore, I will note any resulting differences of words or phrases and provide my own translation for these only when the differences are meaningful. With this in mind, here is Stahl's translation: "Sacred principle of unity amongst the gods, on you I call; you are said to grace weddings with your song; it is said that a Muse was your mother. You bind the warring seeds of the world with secret bonds and encourage the union of opposites by your sacred embrace. You cause the elements to interact reciprocally, you make the world fertile; through you, Mind is breathed into bodies by a union of concord which rules over Nature, as you bring harmony between the sexes and foster loyalty by love. Fair Hymen, you are the main object of the Cyprian's care. Desire, inflamed by Venus, glows on your face. Perhaps because you sing at weddings, which are the province of your mother; or perhaps because the three Graces granted you, their kinsman, the task of garlanding the thresholds blooming with spring flowers-for some such reason, Calliope is glad to have you bless the beginning of her poem concerning the wedding of a god." 
potius edoce quid apportes, et quorsum praedicta sonuerint revelato.'

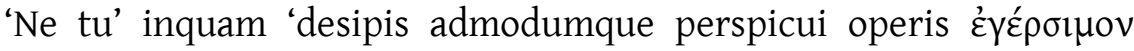
$<$ non $>$ noscens creperum sapis, nec liquet Hymenaeo praeliberante disposita nuptias resultare. si vero concepta cuius scaturriginis vena profluxerint properus scrutator inquiris, fabellam tibi, quam Satura comminiscens hiemali pervigilio marcescentes mecum lucernas edocuit, ni prolixitas perculerit, explicabo. ${ }^{17}$

A preliminary analysis of this twofold prologue shows that the text constructs the figure of the poet/narrator through three different concepts ("union," "elements of the world" and "Hymeneaus") constituted by synonyms and combined by collocation: ${ }^{18}$ The first, alluding to the idea of "union," joins together: copula; thalamis; conubium and is reinforced by a list of verbal processes (foves; socias; ligas; maritas), united by a synonymic relationship of this last term (maritas with conubium). The second chain reunites the "elements of the world," expressed with the terms mundum, elementa, and corporibus. The third chain links the previous ones, and is determined by $t u$, later specified to refer to Hymenaeus, the subject of the

17 "While I was repeatedly reciting these verses of Hymen and pondering some original composition unimagined hitherto, Martianus interrupted me. He could not abide that a grey-haired man living in retirement because of his advance years should chatter stilly trifles, and he said: 'Father, why is it that you are in a hurry to recite before revealing your subject, and, like a sleepy priest, you chant a hymn before you open the entry and the portals? Tell us, rather, the burden and the meaning of your utterance.' I said to him: 'Surely you are joking; you do not recognize like the dawn the opening passage of the work you see me reciting? Since the poem is addressed to Hymen, is it not clear that my theme is a marriage? If, however, your question is serious, when you ask from what source my ideas have flowed, I shall unfold to you a story which Satire invented in the long winter nights and taught me by the dimming lamplight - that is, unless its length discourages you."'

18 For purposes of this work, and in accordance with SFL, I understand "collocation" to mean the cohesive semantic relationship by which a term's use is expected according to the semantic field established by the use of a previous term. For example, if we find a text named The Marriage of Mercury and Philology, it is likely that we will find vocabulary related to the subject, such as "bride", "groom", "union", etc. We expect this, and the text either fulfills or frustrates our expectations, with consequences for the reading. Essentially, collocation works to create cohesion, linking thematic chains and terms. 
whole invocation, and on which depends every other specification expressed by the relative clauses (quem psallentem thalamis; quem matre Camena progenitum perhibent; qui complexuque sacro dissona nexa foves).

These chains are crossed by another transverse chain, related to the process of singing and poetry (cantare; psallentem; carminis). This is thematically related to the "union" chain, since both are verbal processes directed to Hymen, the poetry serving as a means of propitiation. As we will see below, this makes Martianus the poet appear as analogous to Hymen.

\begin{tabular}{|c|c|c|c|}
\hline $\begin{array}{l}\text { Chain 1a } \\
\text { "union" }\end{array}$ & $\begin{array}{c}\text { Chain } 1 b \\
\text { "union" (verbal } \\
\text { processes) }\end{array}$ & $\begin{array}{c}\text { Chain } 2 \\
\text { "elements of the } \\
\text { world" }\end{array}$ & $\begin{array}{c}\text { Chain } 3 \\
\text { "conciliating } \\
\text { agent" }\end{array}$ \\
\hline $\begin{array}{l}\text { copula } \\
\text { thalamis } \\
\text { connubium }\end{array}$ & $\begin{array}{l}\text { maritas } \\
\text { cocias } \\
\text { ligas } \\
\text { foves } \\
\text { cantare } \\
\text { psallentem } \\
\text { carminis }\end{array}$ & $\begin{array}{l}\text { mundum } \\
\text { elementa } \\
\text { corporibus }\end{array}$ & $\begin{array}{l}\text { tu } \\
\text { Hymenaeus }\end{array}$ \\
\hline
\end{tabular}

So in the second paragraph, the discursive verbal processes (mainly

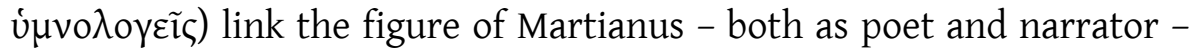
with the first paragraph, in which he sang a hymn; but they also make him an equivalent of Hymen. At the level of poetic creation, Martianus is trying to harmonize the elements shown by the cosmic harmonia at the beginning. The path will be his literary work, and this is represented by a chain about its characteristics: istos versiculos (the deictic shows the extradiegetic level in which this paragraph takes place); nescioquid inopinum intactumque; nugulas ineptas; fabella. The announcement of "something never said or treated before" sounds promising and leads us to expect some kind of revelation. The creator of this narration is Martianus himself, referred to as mi pater respersum capillis albicantibus verticem incrementisque lustralibus decuriatum, and the first person of verbal processes (or the second, when Martianus Junior is speaking): cano, deproperas, edoce, explicabo. This chain is also linked by collocation to the term Satura, 
inspiration of the work, and prosopopeia of the literary genre of De nuptiis. Both narrators, Satura and Martianus, are joined together by one of the few reiterations of the paragraph: the verb edoceo, predicated about both: edoce/edocuit. This comparison locates them in the hierarchic place of magistri, necessary in order to create a didactic instance, establishing a game of parallels: Satura teaches Martianus, and Martianus teaches his son. And so with the definition of the figure of the discipulus, the setting of the didactic stage is completed.

\begin{tabular}{|c|c|c|}
\hline Hymen & Cantare & Thalamos \\
\hline (Martianus) & cantare & 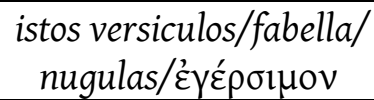 \\
\hline
\end{tabular}

Another chain mediates between narrator and listener, articulated through the axes of light and dark - very frequent metaphors in didactic literature - summing up the didactic project that this section is attempting to present. So we find sapis/desipis; liquet revelato/creperum; nictan-

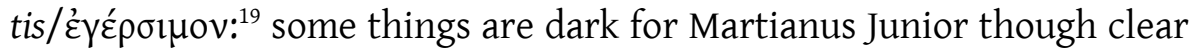
for Martianus pater because of the revelation of the fabella inspired by Satura, which he will immediately reproduce. The word creperum can at first be seen as referring only to the initial hymn, the "obscure" thing Martianus Junior does not understand. But, in a metaphorical operation, the adjective can also be extended to wider and more abstract subjects, such as classical mythology or literature, or even classical culture. The

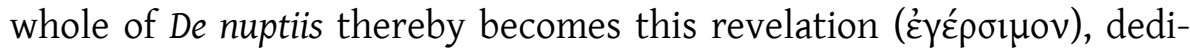
cated to clarifying these obscurities, and Martianus' task takes on major importance. Moreover, the work will create the necessary stimulus to "awaken" the reader to this intended cultural revelation, since, like Martianus Junior, he seems to be a bit lethargic. ${ }^{20}$

19 This chain establishes its relationship with the previous one by collocation, and not by synonyms, as the rest of the terms do. It is the analogy "to see/to awaken" that establishes the link.

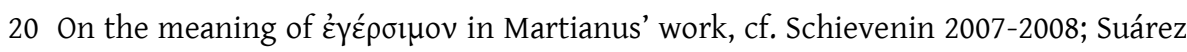
Martínez 2011. In this passage, we prefer the translation related to "beginning," which is more accepted and useful in terms of following the meaning of the text. However, the term also alludes to some "awakening effect," mainly in relation to 


\begin{tabular}{|c|c|c|c|}
\hline $\begin{array}{c}\text { Chain } 1 \\
\text { "literary work- } \\
\text { Revelation" }\end{array}$ & $\begin{array}{l}\text { Chain } 2 \\
\text { "magister- } \\
\text { narrator" }\end{array}$ & $\begin{array}{l}\text { Chain } 3 \\
\text { "discursive } \\
\text { processes" }\end{array}$ & $\begin{array}{l}\text { Chain } 4 \\
\text { "light/ } \\
\text { darkness" }\end{array}$ \\
\hline 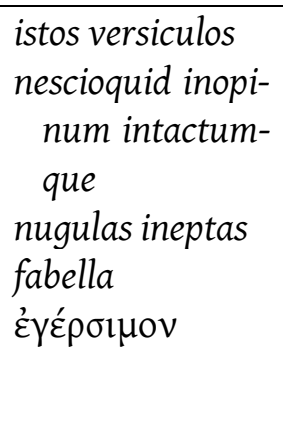 & $\begin{array}{l}\text { mipater } \\
\text { respersum capillis } \\
\text { albicantibus ver- } \\
\text { ticem incre- } \\
\text { mentisque lus- } \\
\text { tralibus decu- } \\
\text { riatum } \\
\text { nictantis antistitis } \\
\text { Satura }\end{array}$ & 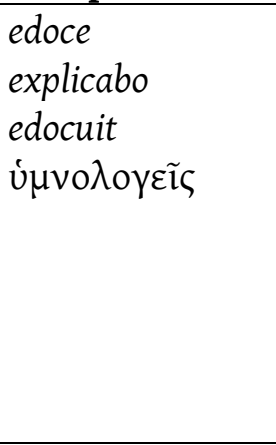 & 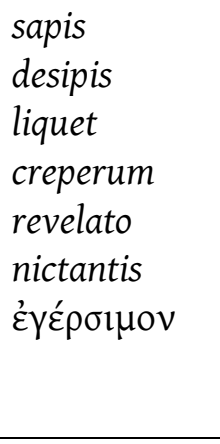 \\
\hline
\end{tabular}

Thus, opposites will be reconciled through singing and poetry, both represented by De nuptiis. Likewise, the objective of the fabella will be to illuminate the darkness, making participation in universal harmony possible. The literary work is the illumination, the revelation, the awakening

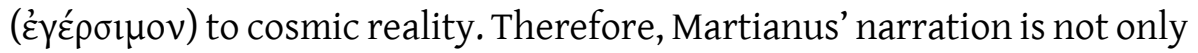
a fabella about the marriage of Mercury and Philology or about the union of discourse and knowledge: ${ }^{21}$ it also embodies the possibility of union between the earthly and the divine. Nevertheless, this bonding entity is also discursive, as we can make out from the processes analyzed in the prologue (all verbs there are related to precise discursive operations),

nictantis, and in this context also means "open the eyes," thus indirectly referring to light. Martianus uses the term again (9.911), in the book dedicated to Harmony, to describe her performance.

21 This is one of the possible allegorical interpretations of the bride and the groom. Other readings suggest they represent the union of the trivium and quadrivium, or the rational part of the soul (Philology) and the divine (Mercury). The complex system of allegories in Martianus includes the assignation of many allegorical referents to a single image, and, inversely, the presence of many images symbolizing only one referent. Thus, unless interpretations are in contradiction, we should not be forced to decide on one over the others, but we should accept that they are at work simultaneously. In any case, Mercury and Philology can represent the divine and the human, and the marriage is the possibility of their conjoining, via the ascent of Philology. On allegory in Martianus' work, cf. Gersh 1986; Shanzer 1986; Ramelli 2001. 
and from the result of these processes itself, which is De nuptiis. Therefore, the general literary subject of the work is discourse itself and its ability to achieve illumination and conciliation.

Nevertheless, the tone of the second paragraph works against this solemnity, and especially against the image of Martianus as a revealed vates. The frame in which the didactical aims are presented becomes a little confusing to the reader, because of the irreverent and sometimes humorous tone, which delineates - even in this early stage of the work an untrustworthy narrator, and a doubtful didactic scenario. This presentation recovers its parodic sense if we observe the strong existing reminiscences of Asclepius, a hermetic treatise widely known in Martianus' times. As we have already noticed, in the second paragraph Martianus is described as a priest who is about to share some revelation. Likewise, at the beginning of the Asclepius, Hermes says to Asclepius:

deus, deus te nobis, o Asclepi, ut divino sermoni interesses, adduxit, eoque tali, qui merito omnium antea a nobis factorum vel nobis divino numine inspiratorum videatur esse religiosa pietate divinior. quem si intellegens videris, eris omnium bonorum tota mente plenissimus, si tamen multa sunt bona et non unum, in quo sunt omnia. alterum enim alterius consentaneum esse dinoscitur, omnia unius esse aut unum esse omnia; ita enim sibi est utrumque conexum, ut separari alterum $\mathrm{ab}$ utro non possit. sed de futuro sermone hoc diligenti intentione cognosces. tu vero, o Asclepi, procede paululum Tatque, nobis qui intersit, evoca. (...) Hammone etiam adytum ingresso sanctoque illo quattuor virorum religione et divina dei completo praesentia, competenti venerabiliter silentio ex ore Hermu animis singulorum mentibusque pendentibus, divinus Cupido sic est orsus dicere: ${ }^{22}$

22 The Latin text of the Asclepius is from Moreschini's edition 1991, and the translation to English is by Copenhaver 1992, who follows Nock's text 1960. Though the Latin texts are different in each case, the few differences in this passage are not relevant here. "'God, Asclepius, god has brought you to us so that you might join in a divine discourse, such a discourse as, in justice, seems more divine in its reverent fidelity than any we have had before, more than any that divine power inspired in us. If you are seen to understand it, your whole mind will be completely full of all good things - assuming that there are many goods and not one good in which all are. Admittedly, the one is consistent with the other: all are of one or all are one, for they are linked 
Leaving aside obvious differences of scene and characters, the situations are analogous. There is an authority figure who will declare a revealing discourse on Truth, there are receptors - respectful and serious in this case - and we also have the figure of a Temple (in Asclepius, real; metaphoric, in De nuptiis). Martianus is the parodic other side of the coin of this solemn and sacred beginning; the humorous comparison of his son points to this direction through lexical affinity: ritu nictantis antistitis, priusquam fores aditumque reseraris (De nuptiis 1); Hammone etiam adytum ingresso sanctoque (Asclepius). Both texts also share the dialogic form, the use of discursive verbs, and the future tenses (explicabo, eris, announcing some kind of transformation in the audience after listening to this revealing discourse), and the secret character of what is about to be re-

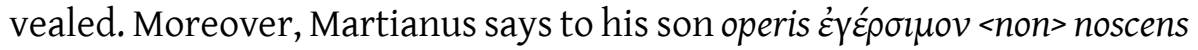
creperum sapis, while Hermes notices quem si intellegens videris, eris omnium bonorum tota mente plenissimus. There is, thus, an asymmetry traced by the axis of knowing / not knowing, which situates Hermes and Martianus as magistri, and their audience as discipuli. In this passage of Asclepius we also find a strong confidence in discourse (sermo) as a revealing agent, which Martianus seems to take up through parodic transformation only to discredit it (istos versiculos, nescioquid inopinum intactumque, nugulas, $f a-$ bella). ${ }^{23}$

so that one cannot be separated from the other. But you will learn this by careful concentration from the discourse to come. Now go out for a moment, Asclepius, and call Tat to join us.' (...) When Hammon had also come into the sanctuary, the reverence of the four men and the divine presence of god filled that holy place; duly silent, the minds and thoughts of each of them waited respectfully for a word from Hermes, and then divine love began to speak."

23 At this point, we should remember that the Asclepius is the only text in the Corpus Hermeticum written in Latin, a translation of the lost Greek text The perfect discourse of Hermes Trismegistus. Throughout the work, the idea of discourse as a transforming force of initiation is demonstrated. In De nuptiis, Mercury is called sermo by Jupiter (1.92-94), but unlike Hermes, his character is somewhat weak and limited, showing no will or power of decision. This can be seen clearly in Book 1, which can be easily compared with a Plautinian comedy, with Mercury as an adulescens amans looking for a wife, all but forced into this by his mother and helped by his brother (Apollo). For an analysis of Mercury's character, cf. Cardigni 2016. 
On the other hand, the mild warnings of Hermes to Asclepius throughout the dialogue find a more vehement echo in the exchanges between Martianus and his son. In paragraph 2 of Asclepius, Asclepius speaks for the first time and asks his teacher after the introduction: Non enim, o Trismegiste, omnis unius qualitatis est anima? o Asclepi, ut celeriter de vera rationis continentia decidisti! ("Is it not true, Trismegistus, that every soul is of the same quality?' 'Asclepius, how quickly you have lapsed from reason's true restraint!"'). Let us remember, in contrast, Martianus junior's question ('quid istud, pater?'), and, in the same tone and register, his father's response: 'Ne tu' inquam 'desipis admodumque perspicui operis

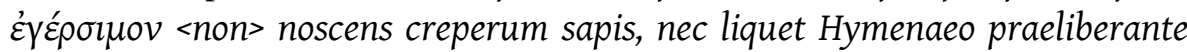
disposita nuptias resultare.'

Therefore, on the hypotext of a hermetic discourse, Martianus constructs himself as a religious authority to declare his discourse, but the irreverent and humoristic context in which these references from Asclepius are actualized is completely inadequate for a hermetic revelation (or any other kind of revelation). The effort that Martianus is nevertheless willing to take in order to convince us is touching, but its efficacy is compromised from the very beginning. The work becomes less a revelation than a discursive misunderstanding. ${ }^{24}$

The perception of parodic register at this initial and programmatic point in the text is fundamental, since it is upon this extradiegetic structure that the remainder of the work will unfold (the fabella), establishing the breakdown of auctoritas and confidence in the narrator. This reading

24 We can also add to this reading the parody of the father-son literature, and recall an example that is similar: that of Macrobius. Two of his works are addressed to his son in the hope of educating him. At the beginning of the first of these, the Commentarii, he addresses Eustatius on two occasions, at the beginning of each book: Eustathi fili, vitae mihi dulcedo pariter et Gloria (1.1) and Eustathi, luce mihi dilectior fili (2.1.1). The second such address takes place in the Preface of Saturnalia, where Macrobius explains to his son his pedagogical intent: Multas variasque res in hac vita nobis, Eustachi fili, natura conciliavit: sed nulla nos magis quam eorum qui e nobis essent procreati caritate devinxit, eamque nostram in his educandis atque erudiendis curam esse voluit, ut parentes neque, si id quod cuperent ex sententia cederet, tantum ulla alia ex re voluptatis, neque, si contra eveniret, tantum maeroris capere possent. On father-son dedications in Roman literature, see also LeMoine 1991. 
key establishes the dominance of the parodic register, as well as the subversion of the content presented.

As a consequence, in the Epilogue we face the final result of this long literary process $(9.997-1000):^{25}$

Habes anilem, Martiane, fabulam, miscillo lusit quam lucernis flamine Satura. Pelasgos dum docere nititur artes †cagris vix amicas Atticis. ${ }^{26}$ sic in novena decidit volumina; haec quippe loquax docta doctis aggerans fandis tacenda farcinat, immiscuit Musas deosque, disciplinas cyclicas garrire agresti cruda finxit plasmate. haec ipsa namque rupta conscientia turgensque felle ac bili, 'multa chlamyde prodire doctis approbanda cultibus possemque comis utque e Martis curia; Felicis' inquit 'sed Capellae flamine, indocta rabidum quem videre saecula iurgis caninos blateratus pendere proconsulari verba dantem culmini tipsoque dudum bobinatore flosculo decertum fulquem iam canescenti rota, $\uparrow$ beata alumnum urbs Elissae quem videt ${ }^{27}$

25 Relihan 1987 has read this Epilogue in a metaliterary way, finding here the statement of the literary genre of Menippean Satire. We can certainly find all of its elements: the mixture, the parody, the dog barking (which links it to the genre's cynical origin), the split of the authorial voice. On the cynical elements in Menippean Satire see also McLuhan 2015.

26 This is a very corrupt passage, in which Dick conjectures artes cathedris uix amias Atticis. However, in his translation, Stahl's seems to be following Willis. (Indeed, he warns about the fact that he is taking Willis's notes of his forthcoming edition into account as he writes his book) and translates cagris as "flesh-hooks," which I accept.

27 Since this passage is extremely corrupt, and Ramelli's text differs from Dick's, I reproduce here Dick's text, since Stahl's translation is based on it: Felicis' inquit 'sed Capellae flemine / indocta rabidum quem uidere saecula / iurgis caninos blateratus pendere, / 


\section{iugariorum murcidam viciniam}

parvo obsidentem vixque respersum lucro, nictante cura somnolentum lucibus ab hoc creatum Pegaseum gurgitem decente quando possem haurire poculo?' testem ergo nostrum quae veternum prodidit secute nugis, nate, ignosce lectitans. ${ }^{28}$

The subjects announced in the Prologue related to "literary work" are here developed, with some repetitions and some novelties; anilem fabulam; miscillo; artes amicas Atticis; in novena volumina; fandis tacenda; Musas deosque; disciplinas cyclicas; and finally, once again nugis, which takes up by synonym nugulas from 1.1. The novelty here is the mention of the disciplinary content of the work, which is absent in the Prologue and until the end of Book 2. It is still a fabula, and still nugae, though now the term adds an ironic meaning aside from that of the initial and topical modesty. But the pretended conciliation has now turned into a mixture (lusit, immiscuit), and the didactic purpose into a simple attempt (docere nititur).

proconsulari uero dantem culmini / ipsoque dudum bombinat ore flosculo / decerptum falce iam canescenti rota, / beata alumnum urbs Elissae quem uidit.

28 "And there, Martianus, you have an old man's tale, a mélange sportively composed by Satire under lamplight as she strove with difficulty to teach the Pelasgian arts dear to Attic fleshhooks. The work is complete in nine books. Our garrulous Satire has heaped learned doctrines upon doctrines, and crammed sacred matters into secular; she has commingled gods and the Muses, and has had uncouth figures prating in a rustic fiction about the encyclopedic arts. Herself distressed by awareness of the triviality of her composition, and swollen with gall and bile, she said: 'I could have come forth in a grand robe, to be admired for my learning and refinement, decorous in appearance, as if just coming from the court of Mars. Instead, I have been inspired by Felix Capella -whom ignorant generations have observed ranting as he passed judgment on barking dogs, giving to the high office of proconsul a bumble bee long separated from his blossoms by the sickle, and in his declining years; a man whom the prosperous city of Elissa has seen as a fosterling settled in a neighborhood of slothful herdsmen, barely managing on a small income, drowsy by day and blinking his eyes with effort - when I could fittingly quaff the Pegasean draught.' And so, my son, in accordance with the testimony of an old man, show indulgence, as you read, for the trifles which he has produced." 
Likewise, the meta-literary Catullian resonances from the term nugae, both in the Prologue and the Epilogue, confront us with Martianus' irony, who clearly frustrates the reader's expectations on the work.$^{29}$ Moreover, the work is a total failure according to what both its narrators say about it, but this is no big surprise for us since the parodic tone at the beginning is a strong caveat of what we are about to read.

The "narrator" chain, incarnated by Martianus and Satura, has now two defined agents: Martianus attributes the narration to Satura, and she - with obvious criticism - to him. After splitting the narrative auctoritas between Martianus and Satura in a very confusing way - since at the beginning, Satura seemed just the inspiration of the work - the text shows both as ridiculous. Satura compares Martianus to a rabid dog - a recurrent image in De nuptiis - while she leaves furious and completes her attack taking up the image of somnolence established by Martianus junior in the Prologue. Light, which had a main function in the initial chains, is now reduced just to one occurrence nictante lucibus and absorbed by its antonymic chain of "darkness".

It is evident that the "awakening" effect that the work was looking for has not been achieved. Martianus himself accepts his defeat, and his last words ask for forgiveness: secute nugis, nate, ignosce lectitans. ${ }^{30}$ Whatever the result of this accidental process of literary creation may be, it certainly has not fulfilled the mission of mediating between the human and the divine, and being thus an ascending path to transcendence: no one

29 One of the levels at which the parodic register operates in a more constant way is that of discursive genres. In this case, the parody is on Catullian nugae, since it is difficult to imagine something more contrary to them than De nuptiis. On other occasions, Martianus reconfigures other discursive genres in a context in which they look ridiculous, such as Epics in the introduction of book 6, full of Virgilian resonances, in order to introduce Rhetoric.

30 Likewise, the lines noticed in the Prologues and the Epilogue run through the rest of the work, intentionally interrupting and framing the expositions of the Liberal Arts. In fact, we have three more interchanges between Martianus and Satura (3.221-22; 6.575-77; 8.806). In all of them, the category of literary work proposed in the Prologue is discussed and the figure of the narrator is attacked and ridiculed because of his inadequacy. These arguments vary in their tone and character; however. Though they start as a kind dialogue in which Satura orientates her pupil, they soon turn into criticism and reproach. We have already seen how the relationship ends. 
has learned anything, there has been no union (as there has been no marriage) and after all is said and done, we are left with a discourse that goes nowhere. So the result of parody is the failure of the work as a didactic text. On the other hand, De nuptiis makes a perfect Menippean satire precisely because of the presence of parody.

Now let's see what happens with the parodic register in the case of the presentation of the Liberal Arts, which is considered a "serious" section, and which has a decidedly different tone. When Arithmetic is about to begin her exposition (7.725), the topic of boredom (taedium, installed by Martianus junior in 1.2) continues. It has been present all along the Arts expositions, but is now reinforced by inadequacy, since it is Voluptas who is complaining, someone much more fitting to preside over a wedding celebration. This impatience reaches its climax before Arithmetic is introduced, when Voluptas again declares the inadequacy of the Arts' speeches, and explicitly suggests that they are delaying the wedding in a dangerous way (7.725):

\section{(...) tunc rursus dia Voluptas}

ipsius aetheria Cylleni immurmurat aure: 'cum doctas superis admirandasque puellas approbat Armipotens, tu optati lentus amoris gaudia longa trahis captumque eludis honorem? seria marcentem stupidant commenta maritum? talia complacita spectat fastidia virgo, nec te cura tori, nec te puer ambit herilis, nec mea mella rapis? quaenam haec hymeneia lex est? in Veneris sacro Pallas sibi vindicat usum; quam melius thalamo dulcis Petulantia fervet! casta maritalem reprimit Tritonia mentem et nuptae non aequa venit; poscenda Dione est, conveniensque tibi potius celebrare Priapum. ${ }^{31}$

31 “Thereupon, heavenly Pleasure once again whispered in the Cyllenian's [Mercury's] ethereal ear: 'While these erudite bridesmaids are impressing the celestial company, and winning the approval of Pallas Athene, will you in your languorous mood put off the pleasures of love you yearned for, and let the prize slip from you when it is in your grasp? Do serious discourses dull the senses of a listless groom? The attractive 
There are clearly two opposing chains here. One we can call Hymeneia lex: Voluptas, maritum; cura tori; mea melle; hymeneia lex; thalamo; nuptiae; Dione; Priapus. The other, headed by Pallas (Pallas; doctas superis admirandasque puellas), is explicitly opposed to the realization of marriage (Casta maritalem reprimit Tritonia mentem). Both chains join in the climax of Voluptas' speech - In veneris sacro Pallas sibi vindicat usum - a clause that very well defines the spirit of this entire erudite section, and the accompanying feeling of inadequacy. In the midst of it all sits Philology - Talia complacita spectat fastidia virgo - silent and observing, a secondary character at her own wedding.

Furthermore, in the same line, the final allusion to the necessity of invoking Priapus brings to light another movement of the text, one centered on "carnalizing" the supposedly spiritual matrimony of Philology and Mercury and reducing it to its sexual aspect. Thus, the final opposition is really between discourse and sex in an anti-allegorical movement that diminishes the value of the matrimony, limiting it to its corporal aspect. So by means of this contrast, the discourses come to represent the inadequate, since not only are they boring and useless in the context at hand, but also pose a serious obstacle to the wedding actually taking place.

And the finally we see how, in contrast to inadequate discourse, silence arises: a space in opposition. The most obvious indication of silence's privileged position within the universe of De nuptiis is in Philology's last prayer during her ascent to the heavens. Unlike those we have seen, this is a serious, introspective passage from which parody is absent. Philology has already prayed twice, to Juno and to Sol, but this third prayer is different. At the end of her ascent, the bride kneels and prays in silence (2.200-8):

maiden observes your indifferent manner. Have you no thought for the nuptial couch; does Venus's son Cupid not entice you; will you not seize my pleasures? Are these the rules of Hymen? Pallas is usurping a rite that belongs to Venus. Far more appropriate for sweet Wantonness to glow in the marriage chamber! The celibate Tritonian [Minerva] depresses the nuptial spirits; she comes to a marriage ill-disposed to the bride. Call for Dione! Far better for you to pay homage to Priapus!"” 
iuxta ipsum extimi ambitus murum annixa genibus ac tota mentis acie coartata, diu silentio deprecatur, veterumque ritu vocabula quaedam voce mentis inclamans secundum dissonas nationes, numeris varia, sono ignota, iugatis alternatisque litteris inspirata, veneraturque verbis intellectualis mundi praesules deos eorumque ministros sensibilis sphaerae potestatibus venerandos, universumque totum infinibilis patris profundidtate coercitum, poscitque quosdam tres deos aliosque diei noctisque septimo radiatos. quandam etiam fontanam virginem

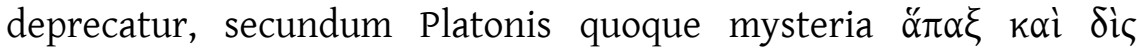

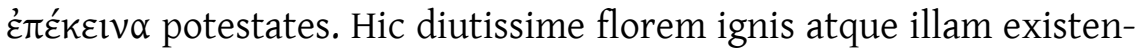
tem ex non existentibus veritatem toto pectore deprecata, tum visa se cernere apotheosin sacraque meruisse. quippe quidam candores lactei fluminis tractim stellis efflamantibus defluebant. ${ }^{32}$

There are two main chains in the first section (from the beginning to torqueri) consisting of movement verbs and contemplation verbs. The

32 "Philology herself leaped down from the palanquin, and saw enormous fields of light, the springtime of heavenly peace; she discerned at one moment the many varied aspects of the decan gods, at another moment she wondered at the eighty-four attendants standing by the heavens; she beheld the very sphere which contains the outermost periphery, driven on at astonishing speed, and the poles, and the quivering axis which from the highest point of heaven pierces the depth of earth and itself makes the whole mass and fabric of heaven revolve; she was aware that the god who was the father of such a work and so great a system had withdrawn even from the very acquaintance of the gods, for she knew that he had passed beyond the felicity that is itself beyond this world, and he rejoiced in an empyrean realm of pure understanding. On her knees, beside the wall of the outer periphery, concentrating the whole attention of her mind, she prayed long in silence, and according to ancient ritual, uttered certain words with her inner voice, words varying in number according to the practice of different peoples, words of unknown sound, made up of alternating combinations of letters. In these words she paid reverence to the presiding deities of the world of pure understanding, and to their ministers, to whom the powers of the sensible world owe veneration, and to the entire universe contained by the depth of the infinite Father; then she invoked those certain three gods and the others who shine on the seventh day and night. She prayed also, according to the mysteries of Plato, to those powers Once and Twice hapax kai dis epekeina, to the Maiden of the Source." 
first chain (desiliens; coercet; raptibus incitatam; vibratum; transmeare; coercitum; as well as defluebant at the end of the paragraph) predominates in the first section and mainly describes the harmonic movement of the universe. The first action (desiliens) is the only one attributed to Philology who in this section is merely contemplating (conspiceret; miraretur; videreat). This verbal process correlates to some other nominal chains, related to "shine" (luminis; fulgentes) and "celestial bodies" (siderum globos et circulorum; sphaeram; molem; stellis). The entire description is full of words and expressions referring to the harmony and quiet of the scene, anticipating a silent atmosphere. ${ }^{33}$

In the second section (from Tanti operis to the paragraph's end), Philology is immersed in chains of knowing (non nesciens; cognoverat) and, most of all, worshipping and praying (deprecatur; venerator; venerandos; deprecatur; poscit; deprecate). She prays in silence (silentio; vocis mente inclamans), and to a series of deities she knows ("non nesciens"). Some of these belong to our world of the senses ("praesules deos eorumque ministros"; "potestatibus") and others are superior to it, deities whom she knows are creators of what she is contemplating (tres deos aliosque; fon-

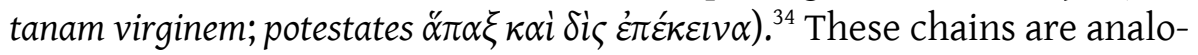
gous and synonymic, but operate in different ontological levels that the text establishes via two other chains: the universe, and a superior instance. In the first, that of the universe, we find totam caeli molem and tanti operis tantaeque rationis, and in the second that of the superior instance, we find, extramundanas beatitudines. From her place between them, Philology contemplates the lower instance, but is able to turn as well to transcendent space (extimi ambitu murum; veritatem existentem ex non existentibus). The Unknown Father, creator of the machina universalis, is above all, separated even from the gods, as Philology notes (secessise ab ipsa notitia deorum), and encompasses everything (empyrio quodam intellectualique mundo gaudentem).

33 Martianus does not even refer to the music of the spheres, as we may expect here, though he treatises it in Book 1. Perhaps the absence of the subject here is an attempt to emphasize silence.

34 The main philosophical source of this passage has been recognized as the Chaldaic oracles, but since Martianus speaks of Platonis mysteria, it is likely that his mention of it here is based on some Platonic source, possibly a Porphyrian commentary. 
We also find a chain in which silence ("silentio") predominates. This is articulated by many discursive terms, but all of these have been covered by the initial silence. They produce "mentis voce," establishing a virtual parallel language that is unheard or unintelligible by humans, since it is non-discursive. Moreover, every term related to language is treated by means of an "estrangement" or "alienation," since the words are unknown and the sounds are mixed in various ways, the letters altered, the result being an unintelligible (non-discursive) language: secundum dissonas nationes; ritu vocabula; numeris varia; sono ignota; iugatis alternatis litteratis inspirata. At the end of the chain is verbis, working as a general term that involves all the previous elements.

With this action, Philology achieves the final goal: apotheosis, as the climax of the paragraph shows through its joining of many chains in one clause (movement, contemplation, transcendence): tum visa se cernere apotheosin sacraque meruisse. This is related synonymously to the previous illam existentem ex non existentibus veritatem toto pectore deprecate.

\begin{tabular}{|c|c|c|c|}
\hline \multicolumn{4}{|c|}{ Philology } \\
\hline Movement & $\begin{array}{l}\text { Contempla- } \\
\text { tion }\end{array}$ & Knowledge & Prayer \\
\hline $\begin{array}{l}\text { desiliens } \\
\text { coercet } \\
\text { raptibus incita- } \\
\text { tam vibratum } \\
\text { transmeare } \\
\text { coercitum } \\
\text { defluebant }\end{array}$ & $\begin{array}{l}\text { conspiceret } \\
\text { miraretur } \\
\text { videreat } \\
\text { luminis } \\
\text { fulgentes }\end{array}$ & $\begin{array}{l}\text { non nesciens } \\
\text { cognoverat }\end{array}$ & $\begin{array}{l}\text { deprecatur ve- } \\
\text { neratur vene- } \\
\text { randos depreca- } \\
\text { tur } \\
\text { poscit } \\
\text { deprecata }\end{array}$ \\
\hline secundum disson & $\begin{array}{r}\text { silentio, vo } \\
\text { Estrange } \\
\text { nationes, ritu } \\
\text { tis alternat }\end{array}$ & $\begin{array}{l}\text { ence } \\
\text { nente inclama } \\
= \\
\text { th in Languag } \\
\text { bula, numeris } \\
\text { teratis inspirc }\end{array}$ & sono ignota, iuga- \\
\hline
\end{tabular}




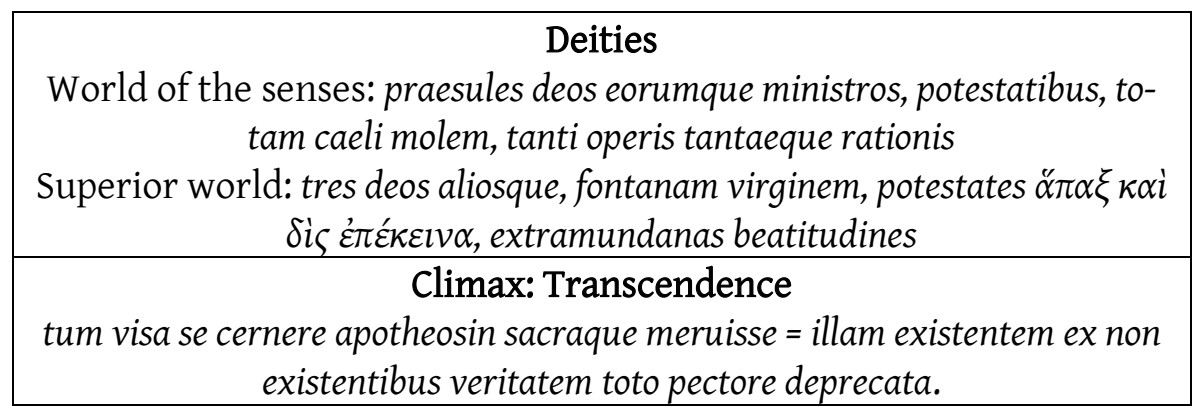

By means of the presentation of silence as a non-parodic instance, this part of the text seems to provide us with another key to reading. If the object of the attack is discourse, how can Martianus realize its opposite - silence - which is inexpressible? By placing the parodic register in retreat and leaving all joking aside with a moment of silence. In the face of union or the desire to attain knowledge, any discourse is inadequate, and we can only be silent.

So we see that as a dominant register - both when it controls and when its absence is significantly apparent - parody functions not only as a unifier but also as a provider of meaning, causing a coherent message to emerge from the work. The sections are neither separate nor disconnected; on the contrary, they are profoundly interconnected and derive their meaning from each other. Furthermore, the parodic reading key transforms the bizarre and unintelligible encyclopedia into a mocking Menippean satire, and all the problems of interpretation that arose from considering it a didactic work are resolved in a new Menippean universe. Martianus joins a tradition that he recognizes and with which he entertains a dialogue, and his social context is reconfigured as one of critique and mockery. The Liberal Arts and their discourses are not a means of didactic instruction, but rather the targets of parody, the product of the plume of a narrator who is misunderstood for his ineptitude. This parodic axis also allows us to detect the emergence of silence as a category that is just as relevant as that of discourse. Silence not only articulates the work's message more clearly; as we will see below, it situates Martianus within the Late Antique literary sphere. 


\section{MARTIANUS AND A "POETICS OF DISCOURSE" IN LATE ANTIQUITY}

This point of view on discourse and on the silence that Martianus alludes to in De nuptiis is not out of keeping with the spirit of his time. The verbosity of the classical world appears to be questioned in Late Antiquity, through the constant problem posed by language and representation, giving way to what has been called "the poetic of silence" (Hernández Lobato 2017). Part of Late Antique reflection in Christian Rome, this phenomenon is the result of a series of inquiries that can be summed up as follows: Is it possible to say something? Is there any reason to continue writing in this context of the end of Antiquity? How is it possible to make discourse after discourse? Unlike certain other rhetorical concerns that had become popular in literary reflections of previous times, the problem now is not what to say or when to say it, but rather whether to say anything. ${ }^{35}$

of course, the ineffable nature of truth was already an old and wellknown problem in the tradition of Platonic philosophy. And discourse and all its fits and passions were the object of reflection by Christian authors as well, Augustine for instance, who concluded that silence was the only valid form of expression, since it represented the language of the heart (Conf. 9.10.23-24). Other writers of the period saw silence not only as an inevitable discursive category, but as something desirable, perhaps

35 In Platonic tradition, for example, "non-discursive" thought is always the preferred form as the path to union with the transcendent, since in theory, the truth cannot be comprehended through a discursive formulation. Basically, it is this distrust of discourse that led Neo-platonic thinkers to develop varied and precise strategies for reading, in order to adequately interpret the texts on which they based their reflections, texts whose truth was accepted as a given and considered a starting point. Within Christianity as well, thinkers who were near contemporaries of Martianus, such as Augustine, reflected on the silent instant of union with the divinity, which includes the explicit recognition that discourse is insufficient and to a certain extent futile and bothersome. As Cullhed 2015: 87 points out, Augustine rejects and dismisses fictitious discourse (and so all discourse, by its nature fictitious) that had played a polemical but dynamic role during Antiquity, at least from Homer and Hesiod onward. 
because discourse is such a farce. Just decades later, in his work, Fulgentius the Mythographer (the first of Martianus Capella's immediate posterity to mention him and his work), reflected on silence as something to which all literary manifestation should aspire (Myth. 11.15-18): Certos itaque nos rerum praestolamur effectus, quo sepulto mendacis Graeciae fabuloso commento quid misticum in his sapere debeat crebrum agnoscamus. ${ }^{36}$ The anonymous poet of the Pervigilium Veneris also makes reference to a concern for this notion of "discourse after discourse" (90-93), since he can only observe, distant and mute - like Philology $y^{37}$ - the comings and goings of nature all about him, waiting for the arrival of a new and powerful voice with which to realize another type of love, of reality:
Illa cantat, nos tacemus. Quando ver venit meum?
Quando faciam uti chelidon, ut tacere desinam?
Perdidi Musam tacendo nec me Phoebus respicit.
Sic Amyclas, cum tacerent, perdidit silentium. ${ }^{38}$

Silence was one of the concerns of the era and directly affected the writing process, functioning paradoxically both as a constraint and as a stimulus for new forms of literary creation. It is no surprise then that Martianus places silence in a prominent position in his composition, though he doesn't appear to be as concerned with establishing the truth of silence as he is with underscoring the fictitious nature of discourse. His premise, then, would be more one of "a poetic of discourse," through which discourse, as the work's protagonist, is explored in all of its forms

36 "And so I seek the true essence of things; only when the fictitious invention of false Greece is buried in silence can we recognize what mystical things our understanding might find in them."

37 A significant difference can be noticed between both works, though, since in the Pervigilium the poet seems to be looking for a new voice to break the silence, unlike Martianus in De nuptiis. However, they are both concerned about silence, and the presence of this interest is my main point here, though of course it can be approached from different perspective in each case.

38 "She sings; we are silent. When shall my spring come? When shall I do as the swallow does and break my silence? In silence have I lost my Muse, and now even Apollo respects me not. Thus Amyclas, when no one spoke, was lost in silence." (The Latin text is Mandolfo's 2012, and the translation is mine). 
and functions, observed to the point of becoming a category. The traditional consideration of fabula-argumentum-historia is thereby dismantled, and the falsity of all discursive formulations is established. They are, after all, but discourse. Silence, the positive pole in this system, does not appear to be so much a revelation of inenarrabilitas, as it is a proposal to rethink the relationship that discourse establishes with reality: that is, representation.

The function of parody in Martianus is to bring Classical Antiquity to a close, shutting off discourse and offering silence as a literary category. The question here is how to move forward, how to narrate silence, how to find a new voice for this new reality. By no means will we find the answer in a Menippean satire like De nuptiis. Martianus' propositum is rather to establish the critique and then back away with a joking gesture. No more can be asked of the work. Its purpose is to invite our reflection - whether it be solemn, nostalgic, indignant or amused- on the problem through which it makes itself a literary work and makes us readers at the same time: the problem of discourse.

\section{BIBLIOGRAPHY}

Bakhouche, B. 2011. 'Martianus Capella's De nuptiis Philologiae et Mercurii or the Subversion of the Latin Novel' in M.P. Futre Pinheiro \& S.J. Harrison (eds.) Fictional Traces. Reception of the Ancient Novel, vol. 2. Groningen, 33-46.

Bakhouche, B. 2015. 'Jeu de miroirs dans les intermèdes auctoriaux des Noces de Philologie et Mercure de Martianus Capella' Latomus 74, 417-40. Cardigni, J. 2016. 'Presencias herméticas en De nuptiis Mercurii et Philologiae de Marciano Capela' Anales de Historia Antigua, Medieval y Moderna 50, 37-53.

Copenhaver, B.P. (ed.) 1992. Hermetica. The Greek Corpus Hermeticum and the Latin Asclepius. Cambridge.

Cullhed, A. 2015. The Shadow of Creusa: Negotiating Fictionality in Late Antique Latin Literature. Berlin.

Dick, A. (ed.) 1925. Martianus Capella. Leipzig. 
Eggins, S. \& Martin, J.R. 2003. 'El contexto como género: una perspectiva lingüística funcional' Revista Signos 36.54, 185-205.

Gersh, S. 1986. Middle Platonism and Neoplatonism: The Latin Tradition. Notre Dame, IN.

Halliday, M.A.K. 1989. Language, Context and Text: Aspects of Language in a Social-semiotic Perspective. Oxford.

Halliday, M.A.K \& R. Hasan 1976. Cohesion in English. London.

Halliday, M.A.K. \& C. Matthiessen 2004. An Introduction to Functional Grammar. London.

Hernández Lobato, J. 2017. 'To speak or not to speak' in J. Elsner \& J. Hernández Lobato (eds.) The Poetics of Late Latin Literature. Oxford, 278-310.

LeMoine, F. 1991. 'Parental Gifts: Father-Son Dedications and Dialogues in Roman Didactic Literature' Illinois Classical Studies 16.1/2, 337-66.

LeMoine, F. 1972. Martianus Capella: A Literary Re-evaluation. Munich.

Lenaz, L. (ed.) 1975. Martiani Capellae De nuptiis Philologiae et Mercurii liber secundus. Padua.

Lewis, C.S. 1963. The Allegory of Love: A Study in Medieval Tradition. Cambridge MA.

McLuhan, E. 2015. Cynic Satire. Newcastle upon Tyne.

Mandolfo, C. (trans.) 2012. Pervigilium Veneris. La veglia di Venere, Introduzione, testo critico e commento a cura di C.M. Acireale. Roma.

Martin, J.R. \& D. Rose 2007. Genre Relations: Mapping Culture. London.

Petrovicova, K. 2009. 'Nescioquid inopinum intactumque moliens cano...: Compositional Aims of De nuptiis Philologiae et Mercurii by Martianus Capella' Graeco-Latina Brunensia 14, 191-209.

Petrovicova, K. 2010. 'Martianus Capella als subversiver Parodist der Fähigkeiten menschlicher Erkenntnis? Frage der Zugehörigkeit von De nuptiis Philologiae et Mercurii zur Gattung der Menippeischen Satire' in Acta Antiqua Academiae Scientiarum Hungaricae 50, 257-65.

Ramelli, I. (trans.) 2001. Marziano Capella. Le nozze di Mercurio et Filologia. Milano.

Ramelli, I. (trans.) 2006. Tutti i commenti a Marziano Capella. Milano.

Relihan, J. 1987. 'Martianus Capella, the Good Teacher' Pacific Coast Philology 22.1/2, 59-70.

Relihan, J. 1993. Ancient Menippean Satire. Baltimore. 
Schievenin, R. 2007-2008. 'Egersimos: risvegli e resurrezioni' Incontri Triestini di Filologia classica 7, 219-232.

Shanzer, D. 1986. A Philosophical and Literary Commentary on Martianus Capella's De Nuptiis Philologiae et Mercurii Book I. Berkeley.

Stahl, W.H. 1971. The Quadrivium of Martianus Capella: Latin Traditions in the Mathematical Sciences, 50 B.C.-A.D. 1250. New York.

Stahl, W.H. (trans.) 1977. The marriage of Philology and Mercury. New York.

Suárez Martínez, P.M. 2011. 'In Martianum Capellam IV: el otro egersimon' Exemplaria Classica 15, 201-11.

Turcan, R. 1954. Ésotérisme et néoplatonisme chez Martianus Capella. Diss. Paris.

Westra, H. 1981. 'The Juxtaposition of the Ridiculous and the Sublime in Martianus Capella' Florilegium 3, 198-214.

Westra, H. 1994. The Berlin Commentary on Martianus Capella's De Nuptiis Philologiae et Mercurii Book I (Mittellateinische Studien und Texte 20). Leiden.

Westra, H. 1998. 'Martianus prae/postmodernus?' Dionysius 16, 115-22.

Willis, J. (ed.) 1983. Martianus Capella. Leipzig.

Julieta Cardigni

Universidad de Buenos Aires

jcardigni@yahoo.es 